\title{
MINIREVIEW
}

\section{Ionic Channels in Smooth Muscle Studied with Patch-Clamp Methods}

\author{
Tadao Tomita \\ Department of Physiology, School of Medicine, \\ Nagoya University, Nagoya, 466 Japan
}

Excitability of smooth muscles varies greatly depending on their location in the body and it is closely related to their physiological function. Since the excitability, i.e. the ability to generate an action potential, is determined by relative contribution of inward and outward currents flowing through the plasma membrane, the different excitabilities are likely to be due to the difference in properties of ionic channels or in distribution of channels. In most nerve fibers, the inward current is carried by $\mathrm{Na}$ ions and the outward current by $\mathrm{K}$ ions, whereas in smooth muscles, it is generally considered that the inward current is mainly carried by $\mathrm{Ca}$ ions and the outward current by $\mathrm{K}[11,59,60]$. Our knowledge on the ionic channels of biological membrane is rapidly expanding particularly after the introduction of the patch-clamp method $[27,45]$. This method has been applied to smooth muscles and information on $\mathrm{Ca}$ channels and $\mathrm{K}$ channels is accumulating. However, due to technical difficulties caused by several factors, such as a small diamter (3-4 $\mu \mathrm{m})$ of muscle fibers and a possible deleterious effect of cell dispersion with enzymes, the application of the patch-clamp method to smooth muscle is still limited compared with cardiac muscles.

Another factor causing the diversity of property in smooth muscle is due to the difference in receptors. There are many different kinds of receptor and the agonistreceptor reaction leads to either contraction (or potentiation of contraction) or relaxation (or inhibition of contraction). Activation of the receptors which are pharmacologically classified to be the same type, for example $\alpha$-adrenoceptors may cause excitation in some smooth muscles, but inhibition in others. In general, these complicated responses may result not only from the membrane process, but also from intracellular process. In the plasma membrane, agonist-receptor reaction may open or close ionic channels and this is an important factor controlling the cellular response. $\mathrm{Ca}$ influx responsible for an agonist-induced contraction is usually considered to be mediated through chemically activated channels which are different from the "voltage-operated Ca channel" involved in action potential, and

Received for publication October 7, 1987 
the chemically activated channel has been termed "receptor-operated Ca channel" [11]. This classification is mainly based on the experimental results showing that the contractions produced by agonists such as acetylcholine or noradrenaline are generally much more resistant to various $\mathrm{Ca}$ channel blockers compared with the contraction produced by excess $\mathrm{K}$ which is likely to be mediated through the "voltage-operated Ca channel." However, the property of the receptor-operated Ca channel is not well understood. In this article, I would like to review the present state of investigation on ionic channels in smooth muscles with the methods using patch electrodes.

\section{VOLTAGE-OPERATED Ca CHANNELS}

With conventional intraceliular recordings, it has been observed that the action potential in many smooth muscles is not much influenced by alteration of the external $\mathrm{Na}$ concentration, resistant to tetrodotoxin, strongly dependent on the external $\mathrm{Ca}$ concentration, and susceptible to various $\mathrm{Ca}$ channel blockers [cf. $11,59,60]$. These results strongly suggest that the $\mathrm{Ca}$ influx is responsible for the action potential. This idea has been confirmed and the properties of inward current are being analyzed in isolated single smooth muscle cells using the "whole-cell recording" to record the total membrane current flowing through the whole surface of a single cell or the "patch-clamp" methods to observe the unitary current flowing through a single $\mathrm{Ca}$ channel.

Vascular muscles are generally quiescent, but small arteries can produce action potentials when the excitatory junction potential exceeds the threshold in response to nerve stimulation. On the other hand, larger blood vessels are unable to generate the action potential by depolarization of the membrane. This is not due to the lack of $\mathrm{Ca}$ channels, but due to an increase in $\mathrm{K}$ conductance upon depolarization, as shown in the rabbit aorta [40]. The presence of $\mathrm{Ca}$ channels can be demonstrated by showing spontaneous spike activity under the condition in which the outward $\mathrm{K}$ current is inhibited by tetraethylammonium (TEA), as observed in the rabbit ear artery [22].

\section{Whole-cell recording}

In the smooth muscle, the inward current carried by $\mathrm{Ca}$ is relatively small compared with the outward current carried by $\mathrm{K}$. Therefore, the whole-cell recordings were generally carried out under the condition in which the $\mathrm{K}$ current was suppressed. In order to block the $\mathrm{K}$ current, TEA (about $20 \mathrm{~mm}$ ) was added to the external medium and $\mathrm{CsCl}(130-140 \mathrm{~mm})$ was used for pipette solution. The action of TEA and $\mathrm{Cs}$ will be described in the section on $\mathrm{K}$ channels. In addition to this, the inward current was usually increased by replacing the external $\mathrm{Na}$ and $\mathrm{Ca}$ with $\mathrm{Ba}(10-120 \mathrm{~mm})$, since $\mathrm{Ba}$ is generally more permeable than $\mathrm{Ca}$ through the $\mathrm{Ca}$ channel. The usage of $\mathrm{Ba}$ has another advantage in reducing the $\mathrm{K}$ current.

With these experimental conditions, the inward current was observed in several 
types of smooth muscle (rabbit urinary bladder [32]; longitudinal muscle of rabbit ileum [20,47,49,55,57]; guinea-pig taenia caeci [26]; guinea-pig and rabbit stomach [42]; toad and amphiuma stomach $[18,19,64]$; rat vas deferens [44]; rat mesenteric artery [1]; rabbit ear artery [21]; dog saphenous vein [66]; culture cell from embryonic rat aorta [24,62]; rat portal vein [36]; culture cell from neonatal rat azygos vein [54].

The inward current was not influenced by complete replacement of $\mathrm{Na}$ with equimolar TEA or tetramethylammonium (guinea-pig urinary bladder [32]), or Tris (with $50 \mathrm{~mm}$ TEA) (longitudinal muscle of rabbit ileum [49]). Tetrodotoxin (10 mM) was also ineffective (stomach [42]; saphenous vein [66]; aorta [24,62]). On the other hand, the inward current was strongly dependent on the external $\mathrm{Ca}$ or $\mathrm{Ba}$ concentrations and readily and reversibly abolished by inorganic polyvalent cations (Ni, Co, Cd, etc.) or organic Ca channel blockers (verapamil, D 600, nifedipine, etc.). Therefore, the inward current is considered to be carried nearly entirely by $\mathrm{Ca}$ ions.

When the external Ca concentration was reduced to less than $0.1 \mu \mathrm{M}$, the inward current in the rabbit ileal cells became sensitive to alteration of external $\mathrm{Na}$ concentrations [49]. The inward current carried by $\mathrm{Na}$ ions is blocked by a $\mathrm{Ca}$ channel blocker, nisoldipine $(0.1 \mu \mathrm{M})$. It seems that $\mathrm{Ca}$ ion controls ionic selectivity of $\mathrm{Ca}$ channel and that $\mathrm{Na}$ ions can pass the $\mathrm{Ca}$ channel under $\mathrm{Ca}$-deficient condition. Similar results have been obtained with the sucrose-gap method in the muscle strips of guinea-pig taenia caeci [12], cat and guinea-pig small intestine [51], and rat myometrium [30].

The maximum intensity of inward current varies in different muscles. The inward current of about $1 \mathrm{nA}$ was recorded from the guinea-pig urinary bladder (3.6 mм Ca [32]) and guinea-pig ileum (10 mm Ba [20]), but the maximum inward current was much smaller even in the presence of $120 \mathrm{~mm} \mathrm{Ba}$ in the rat mesenteric artery (10-50 pA [1]) and $\operatorname{dog}$ saphenous vein (about $100 \mathrm{pA}$ [66]). The current density in the mesenteric artery is estimated to be approximately $1 / 30$ of that in the cardiac (canine ventricle) muscle [1]. It is likely that the channel density in vascular muscles is less than that in the gastrointestinal or urogenital muscles. However, before reaching the conclusion, it is necessary to investigate the variability of current intensity among the cells obtained from the same muscle, and to know a possible cause for the difference such as ionic composition of external and internal media, the way of enzymatic digestion for cell dispersion, the time factor of alteration of intracellular milieu, and temperature, in different experiments.

The difficulty with the whole-cell recording is a gradual decrease in inward current ("run-down") in the course of experiments. In the urinary bladder, the inward current usually disappeared within $5 \mathrm{~min}$ at $35^{\circ} \mathrm{C}$, and this could not be prevented by intracellular cAMP $(0.2-20 \mu \mathrm{M})$ [32]. The improvement was achieved by adding oxalate, pyruvate, and succinate as $\mathrm{K}$ salts ( $5 \mathrm{~mm}$ each) to pipette solution. This was confirmed in the rat vas deferens [44]. It was shown in the longitudinal muscle cells of the rabbit ileum that the inward current was increased 
by intracellular ATP between 0.3 and $10 \mathrm{~mm}$ dose-dependently, not by cAMP [46]. Therefore, the limitation of energy supply is probably one of the factors causing "run-down." In the ileal muscle, however, the inward current declined irreversibly within $10-15 \mathrm{~min}$ at $20-22^{\circ} \mathrm{C}$, even in the presence of $2 \mathrm{~mm}$ internal ATP [20]. Whole cell recordings of stomach muscle cells of an amphibian (Amphiuma tridactylum) which have a much larger dimension (a diameter of $10-15 \mu \mathrm{m}$ ) than the mammalian smooth muscle cells were stable for up to $2 \mathrm{~h}$ [18]. It is likely that the loss of some factor(s) essential for the maintenance of $\mathrm{Ca}$ currents is at least partly responsible for "run-down." Another possibility may be that the cell injury caused by breaking the membrane leads to activation of proteolytic enzyme, which in turn produces toxic effect on the membrane function. In most publications, stability of the inward current was not mentioned. Some experiments were carried out at a room temperature and the others at about $35^{\circ} \mathrm{C}$. However, the relationship between the temperature and the rate of "run-down" is not known.

In the vascular muscles (rat mesentric artery [1]; rat portal veih [36]; dog saphenous vein [66]; cell line (A10) from embryonic rat aorta [24]; primary culture of rat azygos vein [54]), evidence is presented for the existence of two different types of Ca channel. One type is activated by small depolarization ("low threshold") and inactivated relatively quickly ("fast" channels), and the other is activated by large depolarization ("high threshold") and inactivated relatively slowly ("slow" channels). The "fast" and "slow" channels seem to correspond to the "T (transient)type" and "L (long-lasting)-type" of Ca channel in other tissues [39]. In the rat mesenteric artery, the potential for half inactivation was $-41 \mathrm{mV}$ for the fast channel and $-6 \mathrm{mV}$ for the slow channel [1]. In the rat portal vein (short-term primary culture), the "slow" channels also inactivate substantially within $200 \mathrm{~ms}$, although slower than the "fast" channels [36]. This could be due to a high temperature $\left(35^{\circ} \mathrm{C}\right)$, because the other experiments were carried out at $20-25^{\circ} \mathrm{C}$. It is more likely that at least two different $\mathrm{Ca}$ channels also exist in single cells of nonvascular smooth muscles, although their density may differ in different types of smooth muscle. It is interesting to find out properties of the different types of channel in more detail in relation to the regulation of channel kinetics with ATP or second messengers.

As observed in the dog saphenous vein [66], the "solw" (high threshold) channels are generally more permeable to $\mathrm{Ba}$ than $\mathrm{Ca}$, but the "fast" (low threshold) channels are equally permeable to $\mathrm{Ca}$ and $\mathrm{Ba}$. However, in the cell line derived from the rat aorta, substitution of $10 \mathrm{~mm} C$ a with $10 \mathrm{~mm}$ Ba reduced the maximum inward current to nearly half when the holding potential was $-70 \mathrm{mV}$, while when the holding potential was $-50 \mathrm{mV}$, the same procedure increased the current about 6-fold [24], the increase being much larger than that observed in the dog saphenous vein. Thus, the ionic selectivity is apparently different in different smooth muscles, but it may result from the difference in experimental conditions. In the saphenous vein, the experiments were carried out with the pipette solution containing $22 \mathrm{~mm} \mathrm{Cl}$ (aspartate substitute) and $2 \mathrm{~mm} \mathrm{ATP} \mathrm{at} 20-22^{\circ} \mathrm{C}$, whereas in 
the cell line from aorta, the pipette contained $148 \mathrm{~mm} \mathrm{Cl}$ and no ATP (the temperature was not mentioned). This problem should be clarified.

Ca channel blockers are considered to act at the plasma membrane from the outside, because it was shown that intracellular application of flunarzine (rabbit ileum [57]) and D 600 (rabbit ileum, rabbit portal vein [48]) at a concentration of $100 \mu \mathrm{M}$ had no effect on the inward current. In many experiments in which $\mathrm{Ca}$ channel blockers were examined, no distinction was made as to the nature of $\mathrm{Ca}$ channels contributing to the inward current. However, it was shown in the rat mesenteric artery [1] and dog saphenous vein [66], that the "slow" (high threshold) channel was much more sensitive to nitrendipine than the "fast" (low threshold) channel, although both channels were equally affected by inorganic $\mathrm{Ca}$ channel blockers ( $\mathrm{Co}, \mathrm{Cd}$, etc.). The blocking action of nitrendipine was increased by depolarizing the membrane. It was considered, therefore, that nitrendipine binds much more tightly to the inactivated state of the channel. From the changes in the voltage-inactivation curve and assuming $1: 1$ binding, the dissociation constant of nitrendipine was estimated to be $222 \mathrm{~nm}$ at the resting state and $0.46 \mathrm{~nm}$ at the inactivated state in the rat mesenteric artery [1]. According to the similar analysis in the dog saphenous vein, the dissociation constant of nitrendipine was $10 \mathrm{~nm}$ at the resting state and $0.15 \mathrm{~nm}$ at the inactivated state [66].

Similarly, in the urinary bladder, the block of inward current by tiapamil was faster and greater when the stimulation frequency was increased and when the holding potential was more positive [33]. This was interpreted to suggest that tiapamil binds to the $\mathrm{Ca}$ channel at the open state and that unblocking is promoted by hyperpolarization of the membrane. In the longitudinal muscle cells from the rabbit jejunum, it was also found that the blocking action of nicardipine was voltage dependent, shifting the membrane potential-inactivation curve to a hyperpolarizing direction [55]. On the other hand, diltiazem and verapamil inhibited the inward current in a use-dependent manner, the effect being dependent on the frequency and number of stimulation.

As expected from the similar structure to nifedipine or nitrendipine, a $\mathrm{Ca}$ channel agonist, Bay K 8644 also affected the "slow" current without having much effect on the "fast" current. In the guinea-pig ileal cells, Bay K $8644(1 \mu \mathrm{M})$ increased the inward current without a significant effect on its time course and the voltage dependency of activation and inactivation [20]. On the other hand, in the rat mesenteric artery, Bay K 8644 increased the rate of inactivation at $0.2 \mu \mathrm{M}$ [1].

In the cells isolated from guinea-pig and rabbit stomach, the inward current elicited by depolarization from a holding potential of $-80 \mathrm{mV}$ was inhibited by nifedipine, but not by D 600 and diltiazem at a concentration of $1 \mu \mathrm{M}$ [42]. It is important to re-examine this result by clarifying the property ("slow" or "fast" type) of channels.

\section{Patch-clamp recording}

Currents flowing through a single channel were recorded under a cell-attached 
condition from the guinea-pig taenia caeci [67] and aortic cells [18]. Single channels currents were observed when the membrane was depolarized from the resting potential to $-20 \mathrm{mV}$, and the "fast" (low threshold) channels which inactivate quickly were not found. Conditioning hyperpolarization is probably necessary to observe the "low threshold" currents. The conductance of single channel was found to be about $30 \mathrm{pS}$ (with $50 \mathrm{~mm} \mathrm{Ba}$ ) in the taenia and $12 \mathrm{pS}(110 \mathrm{~mm} \mathrm{Ba})$ in the aorta. In the aorta, Bay $\mathrm{K} 8644(10 \mu \mathrm{M})$ prolonged open times and increased the single channels conductance to $15 \mathrm{pS}$.

In the dog saphenous vein, the existence of two different $\mathrm{Ca}$ channels was suggested from the result of whole-cell recordings, as already described, and this was confirmed by patch-clamp (the cell-attached configuration) experiments [66]. In the presence of $90 \mathrm{~mm} \mathrm{Ba}$, the single channel conductance was $8 \mathrm{pS}$ for the low threshold channel and $24 \mathrm{pS}$ for the high threshod channels. When the open time probability was assumed to be 0.4 at $0 \mathrm{mV}$, the number of channels can be estimated from the conductance obtained with whole-cell recording to be $200-400$ /cell for the small conductance channel and 1,200-2,000/cell for the large conductance channel. Bay $\mathrm{K} 8644(0.1 \mu \mathrm{M})$ promoted openings of the high threshold channel with large conductance. When the membrane was depolarized from -80 to $0 \mathrm{mV}$, the histogram of open times could be expressed by single exponential and its time contant was $0.6 \mathrm{~ms}$ in the absence of Bay K 8644, but after application of Bay K 8644 the histogram was fitted by two exponentials, having time constants of 0.55 and $5.4 \mathrm{~ms}$. In both types of channel, the unitary current amplitude was slightly $(15 \%)$ increased by $0.1 \mu \mathrm{m}$ Bay K 8644 .

In the inside-out patch from single cells of the rabbit mesenteric artery, single channel currents were studied in the presence of $80 \mathrm{~mm} \mathrm{Ba}$ and $1 \mu \mathrm{M}$ Bay K 8644 [65]. There were two different channels, having conductances of 8 and $15 \mathrm{pS}$. However, a possible difference of their threshold for activation was not studied. The reversal potential of the currents was about $+60 \mathrm{mV}$ for both channels, and they were not influenced by altering $\mathrm{Na}, \mathrm{K}$, or $\mathrm{Cl}$ concentrations. Thus, ionic selectivity of both channels is very high for $\mathrm{Ba}$. A channel blocker, nisoldipine, inhibited almost completely both types of channel at $50 \mathrm{~nm}$. At $0 \mathrm{mV}$, the apparent dissociation constant for nisoldipine was about $8 \mathrm{~nm}$. If an excised patch is $5 \mu \mathrm{m}^{2}$ and contains one $\mathrm{Ca}$ channel, the total number of $\mathrm{Ca}$ channels in one cell (surface area: $1,600 \mu \mathrm{m}^{2}$ ) is calculated to be about 320 . It is interesting that in this experiment the single channel activity is observed without apparent "run-down" without intracellular ATP. This may be due to inclusion of Bay K $8644(1 \mu \mathrm{M}$ at both sides of the membrane). Alternatively, it may be that some toxic substance is produced in the whole-cell recording.

\section{Ca CHANNELS AFFECTED BY RECEPTOR ACTIVATION}

$\mathrm{Ca}$ influx caused by receptor activation can be effected by several processes. The $\mathrm{Ca}$ channel may be coupled to receptors so that an agonist-receptor reaction 
directly increases the $\mathrm{Ca}$ conductance of the membrane. Alternatively, receptor activation may produce intracellular second messenger(s), such as cyclic nucleotides and this in turn leads to opening of Ca channels. Another process would be that receptor activation depolarizes the membrane due to an increase in conductance for ions other than $\mathrm{Ca}$ and the depolarization secondarily activates the "voltageoperated" $\mathrm{Ca}$ channels. The $\mathrm{Ca}$ channel activated through agonist-receptor reactions, i.e. the "receptor-operated" $\mathrm{Ca}$ channel is considered to be a separate entity from the "voltage-operated" Ca channel. However, their clear distinction is often difficult. There is a possibility that at least some of the "receptor-operated $\mathrm{Ca}$ channel" is a "modified form" of the "voltage-operated Ca channel." Effects of several agonists have been studied electrophysiologically on dispersed single cells. One factor which we should be aware of in the study of receptor-mediated response with patch-clamp experiments is the possibility that a cell dispersion procedure using enzymes might have a deleterious effect on the receptor or the receptorreaction coupling [58].

\section{Acetylcholine}

In the longitudinal muscle cells of the rabbit jejunum, inward currents activated by ionophoretic application of acetylcholine were recorded under the whole-cell clamp condition [6]. The reversal potential of the current was about $+5 \mathrm{mV}$ in the solution containing $45 \mathrm{~mm} \mathrm{~K}\left(E_{\mathrm{K}}=-25 \mathrm{mV}\right)$. Thus, the channel was considered to be poorly selective to $\mathrm{Na}, \mathrm{Ca}$, and $\mathrm{K}$. However, their relative contribution was not studied. The current was decreased with hyperpolarization of the membrane, suggesting that the channel is also controlled by membrane potential. From this experiment, a possibility remains that more than one type of channel are involved in the acetylcholine response.

In the toad (Bufo marinus) stomach muscle (the whole-cell recording), inward currents elicited by depolarization from $-80 \mathrm{mV}$ in the presence of $1.8-54 \mathrm{~mm} \mathrm{Ca}$ were increased and their decay was slowed by acetylcholine [19]. Acetylcholine was effective only on the transient inward current produced by depolarizing pulse, not on the sustained component. No evidence was obtained for the increase in $\mathrm{Na}$ or $\mathrm{Cl}$ permeability by acetylcholine. Mechanism of acetylcholine activation in amphibian muscles seems to differ from that in mammalian muscles. Contribution of intracellular second messenger(s) to their response should be investigated.

\section{Catecholamine}

In the dispersed cells from the guinea-pig pulmonary artery, ionophoretic application of noradrenaline depolarized the membrane at $20-23^{\circ} \mathrm{C}$ [17]. However, the depolarization was not always observed and the degree of depolarization usually declined on repeated application of noradrenaline. When the membrane potential was clamped at $-50 \mathrm{mV}$ in the whole-cell recording configuration, noradrenaline produced an inward current of about $50 \mathrm{pA}$. There was still large inward current in response to noradrenaline when clamped at $E_{\mathrm{K}}$. Therefore, the depolarization 
caused by noradrenaline cannot be explained by the decrease in $\mathrm{K}$ conductane. Furthermore, an increase in membrane conductance was demonstrated by the voltage clamp experiment. It is very likely that $\mathrm{Ca}$ conductance is increased by noradrenaline, but this has yet to be demonstrated.

In the rabbit ear artery (whole-cell recording), which has typical $\alpha_{1}$-receptors, noradrenaline $(10 \mu \mathrm{M})$ did not produce any change in membrane current at a holding potential of $-50 \mathrm{mV}$, but reduced the inward current produced by depolarization [21]. The reduction of inward current is probably not due to an increase in underlying outward current, because the outward $\mathrm{K}$ current was inhibited by internal $\mathrm{Cs}(140 \mathrm{~mm})$, but a contribution of $\mathrm{Cl}$ current cannot be completely disregarded. The effect of noradrenaline was not affected when $10 \mu \mathrm{M}$ cyclic AMP or cyclic GMP was added to the pipette solution, but internal GTP $(0.1 \mathrm{mM})$ was necessary for the recovery of the response. Isoprenaline produced the similar effect in some ( 4 in 18) cells, but many other cells did not respond to isoprenaline, even though noradrenaline was effective in all cells examined. We have confirmed the inhibitory effect of noradrenaline even at less than $1 \mu \mathrm{M}$ on the inward current in the cells of rabbit aorta, which has predominantly $\alpha_{1}$-receptors. Although the recovery of the effect observed with whole-cell clamp was very poor, the first recording from other cells which had been treated with noradrenaline showed just the same response as that of the cell exposed to noradrenaline the first time. The inhibition of inward current contradicts the generation of activity by noradrenaline [41], and expectation of increased intracellular Ca concentration for contraction. The physiological significance of the reduction of $\mathrm{Ca}$ current by noradrenaline remains to be clarified.

\section{$A T P$}

Some smooth muscles are known to have the receptor activated by ATP $\left(\mathrm{P}_{2}\right.$ receptor $[14,15])$. In the whole-cell clamp experiments on cells from the rat vas deferens, ATP $(10 \mu \mathrm{M})$ produced inward current, but this disappeared within $2 \mathrm{~min}$ even in the continuous presence of ATP [43]. The ATP-induced current was not affected by nicardipine $(10 \mu \mathrm{M})$. In the cell-attached patch-clamp, perfusion of pipette with $1 \mu \mathrm{M}$ ATP elicited inward unitary currents. The $V$ - $I$ relationship indicated that a single channel conductance was $20 \mathrm{pS}$ and that the reversed potential was about $0 \mathrm{mV}$, probably due to a poor ionic selectivity.

Similar results were obtained from the rabbit ear artery [4,9]. The reversal potential of the current was also close to $0 \mathrm{mV}$, and channel activity had very weak potential dependency. Substitution of the external $\mathrm{Cl}$ with isethionate or replacement of $\mathrm{Cl}$ in the pipette with gluconate did not affect the ATP response [4]. The channel activated by ATP has a unitary conductance of about $5 \mathrm{pS}$ in $110 \mathrm{~mm} \mathrm{Ca}$ or $\mathrm{Ba}$, and its ionic selectivity of $\mathrm{Ca}$ to $\mathrm{Na}$ is approximately 3 to 1 at near-physiological concentrations [9]. ATP hydrolysis was not necessary for the response, because nonhydrolyzable analogues such as ATP- $\gamma-\mathrm{S}$ or $\alpha, \beta$-methylene ATP are equally effective. Since the current could be recorded in excised patches at internal free $\mathrm{Ca}$ 
concentrations less than $0.01 \mu \mathrm{M}$, the channel was considered to be directly activated by ATP without involvement of second messengers. The current is resistant to blockade with $\mathrm{Cd}(0.5 \mathrm{~mm})$ or nifedipine $(5 \mu \mathrm{M})$, as is generally known for the receptor-operated channel.

\section{Vasopressin}

Whole-cell clamp recordings in the A $7 \mathrm{r} 5$ cell line from an embryonic rat aortic muscle showed that inward current (in the presence of external $10 \mathrm{~mm} \mathrm{Ca}, 40 \mathrm{~mm}$ TEA, and with a pipette containing $140 \mathrm{~mm} \mathrm{KCl,} \mathrm{0.5} \mathrm{mm} \mathrm{EGTA,} 3 \mathrm{~mm}$ ATP, $0.2 \mathrm{~mm}$ $\mathrm{Li}_{2} \mathrm{GTP}, 5 \mathrm{~mm} \mathrm{LiCl}$ ) was markedly inhibited by $10 \mathrm{~nm}$ vasopressin [25]. This result was interpreted that the voltage-operated $\mathrm{Ca}$ channel is blocked by protein kinase $\mathrm{C}$, activated as a result of the cascade reaction caused by activation of phospholipase $\mathrm{C}$ by vasopressin. However, based on the mechanical experiments on the rabbit ear artery, an activator of protein kinase C, 12-O-tetradecanoylphorbol-13acetate (TPA) seemed to cause contraction by increasing the Ca permeability [23]. Further experiments are necessary to clarify the involvement of protein kinase $C$ in $\mathrm{Ca}$ influx. It is expected that our knowledge on the involvement of second messengers in the regulation of $\mathrm{Ca}$ channels will be advanced greatly within a few years.

\section{OUTWARD K CURRENT}

The outward current recorded with the whole-cell clamp method is mainly carried by $\mathrm{K}$ ions. On depolarization of the membrane, an outward current generally increases to a peak which was reached after 100-300 ms and then slowly decayed (the guinea-pig urinary bladder [31]). The transient part of this current is sensitive to Ca and considered to flow through the "Ca-activated $\mathrm{K}$ channels." This channel is activated by intracellular $\mathrm{Ca}$, so that under the whole-cell clamp condition, $\mathrm{Ca}$-influx through the voltage-operated $\mathrm{Ca}$ channel is coupled to the transient outward current. Therefore, a removal of the external $\mathrm{Ca}$, or an application of $\mathrm{Ca}$ channel blockers inhibits this component of outward current (rabbit ilem $[48,49]$ ). When the pipette contained EGTA (about $5 \mathrm{~mm}$ ), the transient outward current was not observed, probably due to efficient chelation of intracellular Ca (dog saphenous vein [66]; rat vas deferens [44]).

Externally applied TEA significantly reduces the K current, but does not block it completely. Using a pipette filled with Cs ion instead of $\mathrm{K}$, the outward current is largely eliminated. 4-Aminopyridine (4-AP; $1-5 \mathrm{mM}$ ) had no effect on the membrane current in the muscle cells from guinea-pig urinary bladder [31] and ileum [49]. However, it was found in the rabbit pulmonary artery that outward currents were inhibited by external application of 4 -AP, by shifting the $V$-I curve towards the depolarizing direction [50]. The effect of 4-AP was much stronger than TEA. The outward current elicited by depolarization from -60 to $+10 \mathrm{mV}$ was reduced to 
half by a low concentration of 4-AP $(0.3 \mathrm{~mm})$, but a high concentration of TEA $(100 \mathrm{~mm})$ was necessary to produce the same effect.

In the cells dispersed from the rabbit jejunum and ear artery, spontaneous transient outward currents ( $100 \mathrm{~ms}$ in duration) were recorded with whole-cell clamp and they were abolished by increasing the EGTA concentration in the pipette to $4-10 \mathrm{~mm}[3,47]$. These currents were considered to be due to activation of $\mathrm{K}$ channels by $\mathrm{Ca}$ cyclically released from the intracellular store. Procaine and A 23187 abolished the current. On the other hand, caffeine $(0.3-1 \mathrm{~mm})$ enhanced the current [47]. When the concentration was increased to more than $3 \mathrm{~mm}$, caffeine transiently increased the frequency and this was followed by a pronounced decrease in current amplitude in both smooth muscles. Acetylcholine on the jejunal cells and noradrenaline on the arterial cells produced the response similar to that caused by caffeine, probably by releasing intracellular $\mathrm{Ca}[3]$ ).

\section{Ca-activated $K$ channels}

The presence of $\mathrm{K}$ channels controlled by intracellular $\mathrm{Ca}$ (Ca-activated $\mathrm{K}$ channels) has been demonstrated in several smooth muscles by recording currents flowing through a single channel with the patch-clamp method (toad and frog stomach [10,52,53,63]; rabbit portal vein [28,29]; rabbit jejunum and guinea-pig mesenteric artery [7, 8]; canine trachea [37]). From the effect of altering ionic composition of the media, it has been shown that these channels are highly selective to $\mathrm{K}$ ions, activated by a low concentration of cytoplasmic $\mathrm{Ca}(0.01-1 \mu \mathrm{M})$, and have a very high conductance ( $200-270 \mathrm{pS}$ at a symmetrical high $\mathrm{K}$ concentration). The high conductance is likely to indicate that the channel has a large pathway, but the high ionic selectivity probably results from the presence of a narrow point in the pathway [35]. In the cells of the toad stomach, the density of Ca-activated $\mathrm{K}$ channel was estimated to be approximately one channel $/ \mu \mathrm{m}^{2}$ [53].

This channel's physiological role is to participate in the refractory period and possibly also in the generation of spontaneous activity [61]. In addition to this, there is some evidence that the Ca-activated $\mathrm{K}$ channel is involved in the catecholamineinduced hyperpolarization in the guinea-pig taenia caeci [13].

Effects of internal $\mathrm{Ca}$ on the channel activity can easily be studied in an "insideout" patch. The open probability (the percentage of the time when the channel is in the open state) is sensitive not only to internal $\mathrm{Ca}$ concentrations but also to membrane potential. Depolarization increases while hyperpolarization decreases the open probability. When the internal Ca concentration is increased, the voltagesensitivity is reduced. However, the voltage-dependency of Ca channel seems to vary from channel to channel even at the same $\mathrm{Ca}$ concentration. It is possible that the channel with a higher affinity to $\mathrm{Ca}$ has a low sensitivity to changes in membrane potential. Furthermore, the channel activity was found to be highly sensitive to internal $\mathrm{pH}$ (rabbit tracheal muscle: unpublished observation). Therefore, it is difficult to clarify the possible difference of channel properties among different smooth muscles. At present, we do not know whether the various degrees of Ca- or 
voltage-dependency represent the difference in channel property under the physiological condition or whether this variation is caused by modification of the channel with experimental conditions.

The relationship between membrane potential and amplitude of single channel currents $(V-I)$ can generally be described by Goldman's constant field equation, assuming that only $\mathrm{K}$ ions contribute to the current:

$$
I_{\mathrm{K}}=P_{\mathrm{K}} \cdot \frac{E F^{2}\left([\mathrm{~K}]_{\mathrm{o}}-[\mathrm{K}]_{\mathrm{i}} \exp (-E F / R T)\right)}{R T(1-\exp (-E F / R T))}
$$

where each symbol has their usual meanings. When $[\mathrm{K}]_{\mathrm{o}}$ and $[\mathrm{K}]_{\mathrm{i}}$ are different, the $V-I$ curves show rectification and when $[\mathrm{K}]_{0}=[\mathrm{K}]_{\mathrm{i}}$, the $V-I$ relationship becomes linear, as predicted from the equation. This was demonstrated in the cells from the guinea-pig mesenteric artery and rabbit jejunum [8] and guinea-gip taenia caeci, and rat myometrium (our own unpublished observations). These results support the idea that this channel has high selectivity to $\mathrm{K}$ ions. At depolarization of more than $+30 \mathrm{mV}$, however, the $V-I$ relationship, particularly when $[\mathrm{K}]_{\mathrm{o}}<[\mathrm{K}]_{\mathrm{i}}$, deviated from the theory. This has been interpreted that other ions $(\mathrm{Na}, \mathrm{Mg}$, etc.) interfere with $\mathrm{K}$ flow [8]. However, this deviation could still be observed in the absence of $\mathrm{Na}$ and $\mathrm{Mg}$ (unpublished observation).

In the guinea-pig mesenteric artery, the distribution of open times of the channel could be fitted by a single exponential at an internal Ca concentration less than $1 \mu \mathrm{M}$, but at $2.5 \mathrm{~mm}$ Ca the distribution consisted of two exponentials, due to appearance of a component of fast openings (having the mean open time of less than $1 \mathrm{~ms}$ ) [8]. The effect of increasing internal Ca concentration was considered mainly to increase the frequency. opening, i.e. shortening of the closed state and partially to prolong the open state. The effect of depolarization was found to be the same as that of increasing $[\mathrm{Ca}]_{\mathrm{i}}$ in the toad stomach cells [53].

When internal $\mathrm{K}(126 \mathrm{~mm})$ was replaced with $\mathrm{Cs}$, the inward $\mathrm{K}$ current was decreased and the current became noisy, probably due to high frequency blocking of the channel by Cs (rabbit jejunum, guinea-pig mesenteric artery [8]). External application of Cs $(1-10 \mathrm{~mm})$ reduced the inward current very effectively and the effect became stronger with hyperpolarization of the membrane.

In cells from rabbit jejunum and guinea-pig mesenteric artery, internally applied Ba did not affect amplitude, but reduced the open probability by lengthening the closed time [7]. The effect became stronger when the voltage drove $\mathrm{Ba}$ into the channel and became weaker when the external $\mathrm{K}$ concentration was increased. These results were interpreted that $\mathrm{Ba}$ ions block the channel by entering the open channel.

In cells of the same preparations, TEA and procaine applied internally reduced unit current amplitude independent of membrane potential and slightly increased mean open times [7]. The concentration of TEA producing a $50 \%$ reduction in unit current was $11.8 \mathrm{~mm}$. The reduction of amplitude was considered to result from 
blocking the open channel at a very high frequency which could not be resolved by the recording system. On the other hand, in our experiments on the rat myometrium in which $1 \mu \mathrm{M}$ Ca was used for the internal medium, TEA significantly reduced the open probability, mainly due to prolonging the closed state of the channel, particularly when the membrane was hyperpolarized. The weak effect of TEA on the kinetics observed in the jejunum and mesenteric artery is probably due to a high concentration of $\mathrm{Ca}(2.4 \mathrm{~mm})$ contained in the internal medium.

In the cells of rabbit portal vein, three different types of Ca-activated $\mathrm{K}$ channel were found $[28,29]$. They were classified in terms of the single channel conductance and the sensitivity to TEA. One type $\left(\mathrm{K}_{\mathrm{L}}\right)$ has a large conductance $(273 \mathrm{pS}$ in average at symmetrical $\mathrm{K}$ concentration of $142 \mathrm{mM}$ ) and the single channel currents were reduced by externally applied TEA $(0.1-1 \mathrm{mM})$. The second type $\left(\mathrm{K}_{\mathrm{S}}\right)$ has a small conductance $(92 \mathrm{pS})$ and the channel was insensitive to TEA [28]. The third type $\left(\mathrm{K}_{\mathrm{M}}\right)$, having a conductance of $180 \mathrm{pS}$, differed from the other channels in that this channel is more sensitive to external $\mathrm{Ca}$ than internal $\mathrm{Ca}$ and more susceptible to internal than external TEA [29].

In cells (primary culture) of the dog tracheal muscle, calmodulin antagonists (haloperidol, trifluoperazine, chlorpromazine) reversibly bind to the Ca-activated $\mathrm{K}$ channel in an open state from the inside and decrease the open probability by shortening the open state and increasing the closed duration in the presence of $1 \mathrm{~mm}$ internal Ca [38]. Dissociation constants were $1.0 \mu \mathrm{M}$ for haloperidol, $1.4 \mu \mathrm{M}$ for trifluoperazine and $2.0 \mu \mathrm{M}$ for chlorpromazine at $21-23^{\circ} \mathrm{C}$. Since the potency of the drugs as calmodulin antagonists is in the order of trifluoperazine $>$ chlorpromazine $>$ haloperidol, the effect on the channel does not support the idea that calmodulin is associated with the channel, as suggested by LACKINGTON and ORREGO [34] for the erythrocyte. We have observed, contrary to the finding on the dog trachea, that when internal $\mathrm{Ca}$ was less than $1 \mu \mathrm{M}$, trifluoperazine and W-7 (a calmodulin antagonist) increased the open probability in the cells from the guinea-pig taenia caeci. Further experiments are necessary to investigate molecular mechanisms of $\mathrm{Ca}$ activation of the channel, including involvement of calmodulin.

\section{Voltage-dependent $K$ channels}

In order to study the voltage-dependent $\mathrm{K}$ current in the rabbit ileal cells, the Ca-dependent component of currents in whole-cell clamp was inhibited by replacing the external Ca with $\mathrm{Mn}(2.5 \mathrm{~mm})$ [56]. Under this condition, depolarization from -60 to $+30 \mathrm{mV}$ produced outward currents which slowly inactivated, taking $0.7-$ $1.5 \mathrm{~s}$ to reach $80 \%$ of the maximum at the room temperature. Diltiazem, verapamil, and nicardipine all reduced the outward current, the concentration to reduce it $50 \%$ being 30,14 , and $4.6 \mu \mathrm{m}$, respectively. Diltiazem slowed, whereas verapamil and nicardipine accelerated, the rate of inactivation. On the other hand, TEA (2-3 mM), which reduced the current to a similar degree, did not affect the inactivation rate.

In the rabbit jejunum cells, $\mathrm{Ca}$-insensitive $\mathrm{K}$ channels were studied in inside-out patches [2]. The open probability increased with depolarization of the membrane in 
the range between -40 to $+40 \mathrm{mV}$. The single channel conductance was about 50 $\mathrm{pS}$ when the external $\mathrm{K}$ was 5.9 and internal $\mathrm{K}$ was $126 \mathrm{~mm}(21-25 \mathrm{C})$. Internal application of TEA $(5-10 \mathrm{~mm})$ blocked outward current completely. Since bath application of TEA rapidly blocked the channel also in cell-attached patches, TEA appears to be highly permeable to the plasma membrane.

\section{OTHER IONIC CURRENTS}

\section{Na channel}

No clear evidence has been presented so far for the existence of $\mathrm{Na}$ channel in smooth muscles under the physiological condition, except for primary cultures of azygos venous muscle cells from neonatal rats [54]. In this cell, the inward current carried by $\mathrm{Na}$ was recorded under whole-cell clamp. This current decayed very rapidly with a half-time of $0.9 \mathrm{~ms}$ to almost zero in the presence of $67.5 \mathrm{~mm} \mathrm{Na}$, $20 \mathrm{~mm} \mathrm{CaCl}_{2}$, and $67.5 \mathrm{~mm}$ TEA, and blocked completely by a high concentration $(60 \mu \mathrm{M})$ of tetrodotoxin. It is interesting to look for $\mathrm{Na}$ channels in other smooth muscles.

\section{Cl channel}

$\mathrm{Cl}$ ions are probably playing important roles in smooth muscles in maintaining the resting potential and in involving in agonist responses. However, analysis of $\mathrm{Cl}$ channel is very limited. In the rat anococcygeus muscle, it was shown with wholecell recording that noradrenaline increased the $\mathrm{Cl}$ conductance of the membrane by probably activating $\alpha_{1}$-adrenoceptor [16]. An iontophoretic application of noradrenaline produced inward current at a holding potential of -50 to $-60 \mathrm{mV}$, and its reversal potential could be explained by the $\mathrm{Cl}$ equilibrium potential. Since $\mathrm{Ca}$ ionophore, A 23187, and caffeine, which releases intracellular $\mathrm{Ca}$, also increased the $\mathrm{Cl}$ conductance, it was considered that the $\mathrm{Cl}$ channel is activated by internal $\mathrm{Ca}$, as for the $\mathrm{Ca}$-activated $\mathrm{K}$ channel. It seems likely that intracellular $\mathrm{Ca}$ mediates either depolarization (excitation) by activating Cl-selective channels or hyperpolarization (inhibition) by activating $\mathrm{K}$-selective channels, depending on the function of the smooth muscle.

\section{Non-selective channels}

The non-selective ionic channels activated by agonists have already been described. Besides these, there is another type of non-selective channel activated by hyperpolarization of the memrbane. In the longitudinal muscle cells of rabbit jejunum, an inward current observed with whole-cell clamp was activated in the range of -60 to $-110 \mathrm{mV}$, and considered to contribute to the slow potential changes responsible for spontaneous activity [5]. The reversal potential of this current was $-24.5 \mathrm{mV}$ which was shifted to a hyperpolarizing direction by reducing the external $\mathrm{Na}$, and to a reversed direction by increasing the external $\mathrm{K}$ concentration, suggesting that this inward rectifying channel is permeable to both 
$\mathrm{Na}$ and $\mathrm{K}$. This current was blocked by externally applied Cs ( $1 \mathrm{~mm})$, but less effectively by $\mathrm{Ba}(10 \mathrm{~mm})$.

\section{SUMMARY}

Application of the patch-clamp technique on smooth muscle has started only a few years ago, but many publications are already emerging. The $\mathrm{Ca}$ and $\mathrm{K}$ channels so far found in smooth muscles seem to be fundamentally similar to those in other tissues. However, it is likely that $\mathrm{Ca}$ channel in smooth muscle is not controlled by cyclic AMP, in contrast to the cardiac muscle. There are at least two different ("fast" and "slow") types of Ca channel, but their relative distribution in different smooth muscles and their physiological significance are not yet fully analyzed. Furthermore, analysis of the receptor-operated Ca channels is still very limited, although these channels are very important for the smooth muscle function. Further careful studies are necessary to examine regulatory mechanisms involved in different types of $\mathrm{Ca}$ channel and to clarify the receptor-operated channel. There are also different (voltage- and Ca-activated) types of $\mathrm{K}$ channel. The Ca-activated $\mathrm{K}$ channel seems predominant in many smooth muscles and regulating their excitability However, $\mathrm{K}$ channels responsible for the resting potential or for spontaneous activity should be defined and also contribution of $\mathrm{K}$ (and other ionic) channels to receptor-mediated responses remains to be investigated.

Key nords: patch-clamp, smooth muscle, ionic channel, membrane current.

\section{REFERENCES}

1. Bean, B. Y., Sturek, M., Puga, A., and Hermsmeyer, K. (1986) Calcium channels in muscle cells isolated from rat mesenteric arteries: Modification by dihydropyridine drugs. Circ. Res., 59: 229-235.

2. Benham, C. D. and Bolton, T. B. (1983) Patch-clamp studies of slow potentialsensitive potassium channels in longitudinal smooth muscle cells of rabbit jejunum. $J$. Physiol. (Lond.), 340: 469-486.

3. Benham, C. D. and Bolton, T. B. (1986) Spontaneous transient outward currents in single visceral and vascular smooth muscle cells of the rabbit. J. Physiol. (Lond.), 381: 385-406.

4. Benham, C. D., Bolton, T. B., Byrne, N. G., and Large, W. A. (1987) Action of externally applied adenosine triphosphate on single smooth muscle cells dispersed from rabbit ear artery. J. Physiol. (Lond.), 387: 473-488.

5. Benham, C. D., Bolton, T. B., Denbigh, J. S., and Lang, R. J. (1987) Inward rectification in freshly isolated single smooth muscle cells of the rabbit jejunum. $J$. Physiol. (Lond.), 383: 401-476.

6. Benham, C. D., Bolton, T. B., and Lang, R. J. (1985) Acetylcholine activates an inward current in single mammalian smooth muscle cells. Nature, 316: 345-347.

7. Benham, C. D., Bolton, T. B., Lang, R. J., and Takewaki, T. (1985) The mechanism of action of $\mathrm{Ba}^{2+}$ and TEA on single $\mathrm{Ca}^{2+}$-activated $\mathrm{K}^{+}$-channels in arterial and 
intestinal smooth muscle cell membranes. Pflügers Arch., 403: 120-127.

8. Benham, C. D., Bolton, T. B., Lang, R. J., and Takewaki, T. (1986) Calciumactivated potassium channels in single smooth muscle cells of rabbit jejunum and guinea-pig mesenteric artery. J.Physiol. (Lond.), 371: 45-67.

9. Benham, C. D. and Tsien, R. W. (1987) A novel receptor-operated $\mathrm{Ca}^{2+}$-permeable channel activated by ATP in smooth muscle. Nature, 328: 275-278.

10. Berger, W., GrygorcyK, R., and Schwarz, W. (1984) Single $\mathrm{K}^{+}$channels in membrane evaginations of smooth muscle cells. Pflügers Arch., 402: 18-23.

11. Bolton, T. B. (1979) Mechanisms of action of transmitters and other substances on smooth muscle. Physiol. Rev., 59: 606-718.

12. Bülbring, E. and Tomita, T. (1970) Effects of Ca removal on the smooth muscle of the guinea-pig taenia coli. J. Physiol. (Lond.), 210: 217-232.

13. Bülbring, E. and Tomita, T. (1987) Catecholamine action on smooth muscle. Pharmacol. Rev., 39: 49-96.

14. BuRnstock, G. (1986) The changing face of autonomic neurotransmission. Acta Physiol. Scand., 126: 67-91.

15. BuRnSTOCK, G. and KenNEDY, C. (1985) Is there a basis for distinguishing two types of $\mathrm{P}_{2}$-purinoceptor? Gen. Pharmacol., 16: 433-440.

16. ByRne, N. G. and LARGE, W. A. (1987) Action of noradrenaline on single smooth muscle cells freshly dispersed from the rat anococcygeus muscle. J. Physiol. (Lond.), 389: 513-525.

17. BYRnE, N. G. and LARGE, W. A. (1987) The action of noradrenaline on single smooth muscle cells freshly dispersed from the guinea-pig pulmonary artery. $B r . J$. Pharmacol., 91: 89-94.

18. Caffrey, J. M., Josephson, I. R., and Brown, A. M. (1986) Calcium channels of amphibian stomach and mammalian aorta smooth muscle cells. Biophys. J., 49: 12371242.

19. Clapp, L. H., Vivaudou, M. B., Walsh, J. V., and Singer, J. J. (1987) Acetylcholine increases voltage-activated $\mathrm{Ca}^{2+}$ current in freshly dissociated smooth muscle cells. Proc. Natl. Acad. Sci. U.S.A., 84: 2092-2096.

20. Droogmans, G. and Callewaert, G. (1986) $\mathrm{Ca}^{2+}$-channel current and its modification by the dihydropyridine agonist BAY $\mathrm{K} 8644$ in isolated smooth muscle cells. Pflügers Arch., 406: 259-265.

21. Droogmans, G., Declerck, I., and Casteels, R. (1987) Effect of adrenergic agonists on $\mathrm{Ca}^{2+}$-channel currents in single vascular smooth muscle cells. Pflügers Arch., 409: $7-12$.

22. Droogmans, G., Raeymaekers, L., and Casteels, R. (1977) Electro- and pharmacomechanical coupling in the smooth muscle cells of the rabbit ear artery. J. Gen. Physiol., 70: 129-148.

23. Forder, J., SCRiabine, A., and Rasmussen, H. (1985) Plasma membrane calcium flux, protein kinase-C activation and smooth muscle contraction. J. Pharmacol. Exp. Ther., 235: 267-273.

24. Friedman, M. E., Suarez-Kurtz, G., Kaczorowski, G. J., Katz, G. M., and Reuben, J. P. (1986) Two calcium currents in a smooth muscle cell line. Am. J. Physiol., 250: H699-H703.

25. Galizzi, J.-P., Qar, J., Fosset, M., Van Renterghem, C., and Lazdunski, M. (1987) Regulation of calcium channels in aortic muscle cells by protein kinase $C$ activators (diacylglycerol and phorbol esters) and by peptides (vasopressin and 
bombesin) that stimulate phosphoinositide breakdown. J. Biol. Chem., 262: 69476950.

26. Ganitkevich, V. Ya., Shuba, M. F., and Smirnov., S. V. (1986) Potential-dependent calcium inward current in a single isolated smooth muscle cell of the guinea-pig taenia caeci. J. Physiol. (Lond.), 380: 1-16.

27. Hamill, O. P., Marty, A., Neher, E., Sakmann, B., and Sigworth, F. J. (1981) Improved patch-clamp techniques for high-resolution current recording from cells and cell-free membrane patches. Pfü̈gers Arch., 391: 85-100.

28. Inoue, R., Kitamura, K., and Kuriyama, H. (1985) Two Ca-dependent K-channels classified by the application of tetraethylammonium distribute to smooth muscle membranes of the rabbit portal vein. Pflügers Arch., 405: 173-179.

29. Inoue, R., Okabe, K., Kitamura, K., and Kuriyama, H. (1986) A newly identified $\mathrm{Ca}^{2+}$ dependent $\mathrm{K}^{+}$channel in the smooth muscle membrane of single cells dispersed from the rabbit portal vein. Pflügers Arch., 406: 138-143.

30. JMari, K., Mironneau, C., and Mironneau, J. (1987) Selectivity of calcium channels in rat uterine smooth muscle: Interactions between sodium, calcium and barium ions. J. Physiol. (Lond.), 384: 247-261.

31. Klöckner, U. and IsEnBERG, G. (1985) Action potentials and net membrane currents of isolated smooth muscle cells (urinary bladder of the guinea-pig). Pflügers Arch., 405: 329-339.

32. KlöCKNER, U. and IsEnBERG, G. (1985) Calcium currents of cesium loaded isolated smooth muscle cells (urinary bladder of the guinea-pig). Pflügers Arch., 405: 340-348.

33. KlöcKner, U. and IsenberG, G. (1986) Tiapamil reduces the calcium inward current of isolated smooth muscle cells. Dependence on holding potential and pulse frequency. Eur. J. Pharmacol., 127: 165-171.

34. Lackington, I. and OrRego, F. (1981) Inhibition of calcium-activated potassium conductance of human erythrocytes by calmodulin inhibitory drugs. FEBS Lett., 133: 103-106.

35. Latorre, R. and Miller, C. (1983) Conduction and selectivity in potassium channels. J. Membr. Biol., 71: 11-30.

36. Loirand, G., Pacaud, P., Mironneau, C., and Mironneau, J. (1986) Evidence for two distinct calcium channels in rat vascular smooth muscle cells in short-term primary culture. Pflïgers Arch., 407: 566-568.

37. MCCann, J. D. and Welsh, M. J. (1986) Calcium-activated potassium channels in canine airway smooth muscle. J. Physiol. (Lond.), 372: 113-127.

38. MCCANN, J. D. and Welsh, M. J. (1987) Neuroleptics antagonize a calcium-activated potassium channel in airway smooth muscle. J. Gen. Physiol., 89: 339-352.

39. McCleskey, E. W., Fox, A. P., Feldman, D., and Tsien, R. W. (1986) Different types of calcium channels. J. Exp. Biol., 124: 177-190.

40. Mekata, F. (1976) Rectification in the smooth muscle cell membrane of rabbit aorta. J. Physiol. (Lond.), 258: 269-278.

41. Mekata, F. (1979) Studies of the electrical excitability of aorta smooth muscle of rabbit. J. Physiol. (Lond.), 293: 11-21.

42. Mitra, R. and Morad, M. (1985) $\mathrm{Ca}^{2+}$ and $\mathrm{Ca}^{2+}$-activated $\mathrm{K}^{+}$currents in mammalian gastric smooth muscle cells. Science, 229: 269-272.

43. NAKAZAWA, K. and MATSUKI, N. (1987) Adenosine triphosphate-activated inward current in isolated smooth muscle cells from rat vas deferens. Pfügers Arch., 409: $644-646$. 
44. Nakazawa, K., Matsuki, N., Shigenobu, K., and Kasuya, Y. (1987) Contractile response and electrophysiological properties in enzymatically dispersed smooth muscle cells of rat vas deferens. Pflügers Arch., 408: 112-119.

45. NeHER, E. and SaKmanN, B. (1976) Single-channel currents recorded from membrane of denervated frog muscle fibres. Nature, 260: 799-802.

46. Ohya, Y., Kitamura, K., and Kuriyama, H. (1987) Modulation of ionic currents in smooth muscle balls of the rabbit intestine by intracellularly perfused ATP and cyclic AMP. Pflügers Arch., 408: 465-473.

47. Ohya, Y., Kitamura, K., and Kuriyama, H. (1987) Cellular calcium regulates outward currents in rabbit intestinal smooth muscle cell. Am. J. Physiol., 252: C401C410.

48. Ohya, Y., Terada, K., Kitamura, K., and Kuriyama, H. (1987) D600 blocks the $\mathrm{Ca}^{2+}$ channel from the outer surface of smooth muscle cell membrane of the rabbit intestine and portal vein. Pflügers Arch., 408: 80-82.

49. Ohya, Y., Terada, K., Kitamura, K., and Kuriyama, H. (1986) Membrane currents recorded from a fragment of rabbit intestinal smooth muscle cell. Am. J. Physiol., 251: C335-C346.

50. Okabe, K., Kitamura, K., and Kuriyama, H. (1987) Features of 4-aminopyridine sensitive outward current observed in single smooth muscle cells from the rabbit pulmonary artery. Pflügers Arch., 409: 561-568.

51. Prosser, C. L., Kreulen, D. L., Weigel, R. J., and Yau, W. (1977) Prolonged potentials in gastrointestinal muscles induced by calcium chelation. Am. J. Physiol., 233: C19-C24.

52. Singer, J. J. and W ALSH, J. V. (1984) Large conductance $\mathrm{Ca}^{2+}$-activated $\mathrm{K}^{+}$channels in smooth muscle cell membrane. Reduction in unitary currents due to internal $\mathrm{Na}^{+}$ ions. Biophys. J., 45: 68-70.

53. Singer, J. J. and WALSH, J. V. (1987) Characterization of calcium-activated potassium channels in single smooth muscle cells using the patch-clamp technique. Pflügers Arch., 408: 98-111.

54. Sturek, M. and Hermsmeyer, K. (1986) Calcium and sodium channels in spontaneously contracting vascular muscle cells. Science, 233: 475-478.

55. Terada, K., Kitamura, K., and Kuriyama, H. (1987) Blocking actions of $\mathrm{Ca}^{2+}$ antagonists on the $\mathrm{Ca}^{2+}$ channels in the smooth muscle cell membrane of rabbit small intestine. Pflügers Arch., 408: 552-557.

56. Terada, K., Kitamura, K., and Kuriyama, H. (1987) Different inhibitions of the voltage-dependent $\mathrm{K}^{+}$current by $\mathrm{Ca}^{2+}$ antagonists in the smooth muscle cell membrane of rabbit small intestine. Pfü̈gers Arch., 408: 558-564.

57. Terada, K., Ohya, Y., Kitamura, K., and Kuriyama, H. (1987) Actions of flunarzine, $\mathrm{a} \mathrm{Ca}^{++}$antagonist, on ionic currents in fragmented smooth muscle cells of the rabbit small intestine. J. Pharmacol. Exp. Ther., 240: 978-983.

58. Tokuno, H. and TомгтA, T. (1987) Collagenase eliminates the electrical responses of smooth muscle to catecholamines. Eur. J. Pharmacol., 141: 131-133.

59. TомгтA, T. (1981) Electrical activity (spikes and slow waves) in gastrointestinal smooth muscles. In: Smooth Muscle: An Assessment of Current Knowledge, ed. by Bülbring, E., Brading, A. F., Jones, A. W., and Tomita, T., Edward Arnold, London, pp. 127-156.

60. Томіта, T. (1982) Ionic basis of smooth muscle action potentials. In: Handbook of Experimental Pharmacology, ed. by BerTaCcinI, G., Springer-Verlag, Berlin, Vol. 59I, 
pp. 79-115.

61. Tomita, T. and Watanabe, H. (1973) Factors controlling myogenic activity in smooth muscle. Philos. Trans. R. Lond. B., 265: 73-85.

62. Toro, L. and Stefani, E. (1987) $\mathrm{Ca}^{2+}$ and $\mathrm{K}^{+}$currents in cultured vascular smooth muscle cells from rat aorta. Pflügers Arch., 408: 417-419.

63. WALSH, J. V. and Singer, J. J. (1983) $\mathrm{Ca}^{2+}$-activated $\mathrm{K}^{+}$channels in vertebrate smooth muscle cells. Cell Calcium, 4: 321-330.

64. W Alsh, J. V. and Singer, J. J. (1987) Identification and characterization of major ionic currents in isolated smooth muscle cells using the voltage-clamp technique. Pflügers Arch., 408: 83-97.

65. Worley, J. F., Deitmer, J. W., and Nelson, M. T. (1986) Single nisolidipine-sensitive calcium channels in smooth muscle cells isolated from rabbit mesenteric artery. Proc. Natl. Acad. Sci. U.S.A., 83: 5746-5750.

66. Yatani, A., Seidel, C. L., Allfen, J., and Brown, A. M. (1987) Whole-cell and singlechannel calcium currents of isolated smooth muscle cells from saphenous vein. Circ. Res., 60, 523-533.

67. Yoshino, M. and YABU, H. (1985) Single Ca channel currents in mammalian visceral smooth muscle cells. Pflügers Arch., 404: 285-286. 